\title{
Schooling in violent situations: The politicization of education in Nepal, before and after the 2006 peace agreement
}

\section{Tejendra J. Pherali}

Tejendra J. Pherali

IM Marsh Campus, Liverpool John Moores University

Liverpool L17 6BD

United Kingdom

T.Pherali@ljmu.ac.uk

\begin{abstract}
This article examines the contentious relationship between education and the Maoist insurgency in Nepal, analyzing the political intrusion on the education sector before and after the multi-party polity was restored in 1990, and the violent experiences of teachers and students during the decade-long conflict (1996-2006). It argues that the end of the conflict in 2006 has merely reduced the tangible attacks on education, as the political interference in the education system continues. During the post-accord transition, schools symbolize power centres in the community which provide a space for multi-party political scuffles.
\end{abstract}

Keywords: conflict, peacebuilding, politicization of education, violence, children, teachers, Nepal, People's War, post-war, post-conflict; role of education; education reform; schools

The field of education and conflict has attracted increasing interest from academics in education and conflict studies as well as from policymakers and practitioners (Davies 2004; Novelli and Cardozo 2008; Østby and Urdal 2011; Paulson and Rappleye 2007). Theoretical arguments on the nexus between education and civil war mainly engage in two facets of this relationship — the manifold effects of violent conflicts on education (Seitz 2004; Lai and Thyne 2007; UNESCO 2010, 2011) and the various ways education can reduce or contribute to conflict (Bush and Saltarelli 2000; Davies 2004; Smith 2005). The onset and rapid 
expansion of Nepal's People's War (1996-2006) illustrates how deeply-rooted socioeconomic disparities lead to an environment being conducive to insurgency (Lawoti 2010). The violent uprisings that emerge in such contexts often capitalize on people's grievances and mobilize the masses, both to oppose the regime and to target wider socio-cultural structures. In this process, education plays a crucial role.

In this article I focus on the complex and multifaceted interactions between education and Nepal's decade-long People's War, declared on 13 February 1996 by CPN-M, the Communist Party of Nepal (Maoist), later known as the UCPN-M, or United Communist Party of Nepal (Maoist). The conflict claimed the lives of over 13,347 people (INSEC 2007) and did irreversible social, educational, and economic damage before the Government of Nepal and the CPN-M signed the Comprehensive Peace Accord (CPA) on 21 November 2006. Drawing on two qualitative studies, conducted during June to October of 2008 and February to March of 2011, I present a critical analysis of educational development in Nepal from a conflict perspective and examine the impact of armed conflict on education using the narratives of teachers and parents who experienced the conflict (Riessman 1993).

The first study was carried out in eight selected schools from six districts across Nepal's various geographic regions: Doti, Rolpa, Kapilvastu, Kathmandu, Udaypur, and Sankhuwasabha. Doti is in the Far Eastern Region and Rolpa in the Mid-Western Region, where the People's War began. Kapilvastu is in the Western Plains bordering India where the Maoist conflict was recently followed by severe ethnic/religious violence, and Kathmandu, the capital, is in the Central Region. Finally, Udaypur is in the South Eastern Region and Sankhuwasabha in a mountainous district in the North Eastern Region. Clearly, these regions represent diverse cultural, political, and economic circumstances, particularly in terms of "horizontal inequalities" across social groups from different ethnic, caste, and cultural backgrounds (Stewart 2000; Tiwari 2010a). The schools also represent other forms of diversity: they are privately managed and government supported, urban and rural, and severely or moderately affected by violent conflict. At each sample school, eight to twelve teachers and the same number of parents participated in separate focus group discussions and the head teacher of each school took part in an extensive interview, recounting a range of personal and professional experiences during the conflict. The interviews were digitally recorded and transcribed verbatim; I then conducted a thematic analysis of the respondents' experience of conflicts and their "perceptions" (Silverman 2010, p. 48) of the post-war politicization of educational processes (Grbich 2007). 
Later, I was involved in a broader study into the political economy of Nepal's educational reforms (DFID 2009), which was conducted mainly in eight districts in Nepal: Doti, Banke, Rolpa, Kapilvastu, Rupandehi, Kathmandu, Dhanusha, and Sankhuwasabha. The researchers interviewed 256 educational stakeholders, including school teachers, children, parents, and members of school management committees, as well as politicians, NGO workers, and representatives from Nepal's development partners in the education sector.

As I shared much of the sociocultural background of the research participants, this led to a reflexive process of inquiry in which perceptions and meanings of experiences were coconstructed and illuminated by the researcher as a "reflexive insider" (Alvesson and Sköldberg 2009). The insider researcher is a member of "specified groups and collectivities or occupants of specified social statuses" (Mercer 2007, p. 3) and therefore, has a "lived familiarity with the group being researched" and enjoys "privileged" access to particular kinds of knowledge (Griffith 1998, p. 361; Merton 1972). In addition, my fieldwork in both studies involved an extended period of engagement with local communities, so I could adopt a semi-ethnographic approach to investigate the impact of conflict in the post-war situation. My analysis draws upon various theories within the broader frame of conflict theory, such as education as cultural reproduction (Bourdieu 1984), education and hegemony (Apple 2004; Gramsci 1971), and the notion that, during conflict, education can have "two faces" (Bush and Saltarelli 2000).

Bourdieu's (1984) notions of cultural and social reproduction explain that education plays a key role in perpetuating the existing social order by recognizing the cultural heritage of the culturally and politically dominant social groups. The education system demands linguistic and cultural competence from the privileged social groups (e.g. the middle class, upper castes, historically dominant ethnic groups, and males) who prepossess the necessary cultural capital and familiarity with what is transmitted as legitimate knowledge in educational institutions. In Nepal, the upper-caste males, who were culturally and educationally privileged even before the arrival of modern education, continued to exercise educational "hegemony" (Gramsci 1971) even during the period when educational provision was relatively egalitarian. By reproducing social and economic disparities, the "negative face" of education played a complicit role in generating and fuelling the armed conflict (Bush and Saltarelli 2000). I will apply these theoretical concepts throughout the article as I analyse the interaction between education and conflict in Nepal.

The article contains three main sections. First, I highlight the contentious role of education in the emergence and growth of the People's War. Then, in the second section, I 
analyze violence against schools. In the final section I discuss educational developments since the CPA and argue that the end of the major conflict in 2006 has merely reduced the tangible attacks on education while maintaining multiple forms of political interference with the school system. This has been further exacerbated by the fact that development partners emphasize technical solutions to educational problems rather than challenge the national government to attend to the longstanding structural problems within the education system in Nepal. In the post-accord transition, schools symbolize power centres in the community, providing a space for multi-party political scuffles.

\section{The People's War in the land of Buddha}

Until 1996, Nepal was generally known to the outside world as a Zone of Peace, the birthplace of Buddha whose preaching of peace, love, and compassion spread across the world. In fact, at the 1973 summit of the Nonaligned Movement in Algiers, King Birendra (1945-2001) formally proposed that Nepal be declared a Zone of Peace; the proposal had been endorsed by 110 nations as of 1991. But in 1996, the emergence of the Maoist rebellion converted the country into a battlefield. The insurgency was launched after long ideological preparation and well-founded strategic planning, as Maoist leaders, including Prachandra, the party chair, revealed in television interviews in 2007 and 2008. This planning combined the political struggles of the party and its sister organizations with guerrilla warfare carried out by its military wing: the People's Liberation Army (PLA). The movement's overall aim was to capture state power and establish "a new democratic socio-economic system and state" by ousting the existing "semi-feudal" state structures (Bhattarai 2003, p. 117).

Earlier popular uprisings and revolts against autocratic regimes had failed to transform the unjust socio-economic structures of Nepali society. Nepal experienced the overthrow of the Rana oligarchy (1846-1950), the advent of democracy in 1951, King Mahendra's no-party panchayat system (1961-1990) and the restoration of a multi-party polity with a supposedly constitutional monarchy (1990 onwards). None of these successfully addressed the grievances of ordinary people; they primarily benefited the hill-based high-caste groups, particularly the Brahmins and Chhetris who monopolized state power (Lawoti 2005). In Nepal's hierarchical caste system, Brahmins, Chhetris, and Newars are considered the upper castes, while indigenous groups, such as the Magar, Gurung, Sherpa, Rai and Limbu, are treated as lower castes. The Dalits, at the bottom of the hierarchy, have traditionally suffered as an untouchable caste. 
The Maoists' forty-point demands — which were submitted to the government together with the declaration of the People's War - also stressed political, economic, and socio-cultural inequalities as the rationale for an armed rebellion in Nepal (Maoist Statements and Documents 2003). The major aim of the armed struggle was to establish a political system that would address the needs of marginalized groups, including ethnic minorities, women, subordinate castes, and indigenous groups (Bhattarai 2003). Calling on the population to participate in the rebellion, one of the leaflets widely distributed across the country in February 1996 read, "March along the path of the People's War to smash the reactionary state and establish a new democratic state".

The conflict started in some of the most deprived regions of the country, Rolpa and Rukum districts in the mid-west hills, primarily inhabited by an ethnic minority group called Kham Magars who were significantly underrepresented in the state apparatus and historically neglected by the Kathmandu-based power centre (for a detailed analysis, see Lawoti 2010). These areas provided not only popular support for the Maoists, but also "a pool of recruits to launch the opening moves of the insurgency" (Rappleye 2011, p. 63). By 2002, the war had spread across the country engulfing 73 out of 75 districts, claiming the lives of approximately 8,000 people and causing enormous economic losses (Kumar 2003).

This rapid expansion is widely attributed to three factors: spatial and horizontal inequality along caste and ethnic lines (Murshed and Gates 2005; Tiwari 2010a), the political failure or inefficiency of the post-1990 governments to address the insurgency in its early stage (Bohara, Mitchell, and Nepal 2006; Thapa and Sijapati 2004) and, most importantly, poverty (Bhattarai 2003; Deraniyagala 2005; Do and Iyer 2007). More recently, inequalities in the level of development and the unwanted outcomes of development efforts have been identified as two more explanatory factors in the emergence of violent conflict in Nepal (Rappleye 2011; Tiwari 2010b). The national education system either fell short in addressing these huge structural problems or played a complicit role in reinforcing inequalities by excluding certain social groups from the national development process.

This situation not only exacerbated "horizontal inequalities" across ethnic and caste groups (Tiwari 2010a) but also posed an imponderable challenge to achieving equitable social adjustments to reduce structural marginalization. As Gramsci (1971, p. 43) noted, when a society produces "a new stratum of intellectuals [...] from a social group which has not traditionally developed the appropriate attitudes", it has "unprecedented difficulties to overcome". The liberal meritocratic model of Nepal's education system mainly benefited the children from the upper castes who had historically enjoyed the social, cultural, and political 
privileges. Gramsci (1971, p. 42) also challenges the ideology of meritocracy; focusing on the child of a traditionally intellectual family, he explains that even before that child "enters the classroom he has numerous advantages over his comrades and is already in possession of attitudes learnt from his family environment". In other words, members of socially underprivileged groups experience a serious cultural disconnection from the education system that is created by those in power. Though educational provision is available, children from the marginalized communities, such as Dalits, indigenous nationalities, and Madheshis, continue to underachieve in school and are still more likely to drop out of school than those from other backgrounds (Yadava 2007).

\section{Politics, education, and conflict in Nepal}

Throughout the history of Nepal, the education sector has always been at the epicentre of political movements. In 1971, the government introduced the National Education System Plan (NESP), a policy initiative that allowed it to begin systematically controlling public education through centralized management of schools and implementation of a national curriculum. Since then, student movements have often surpassed the education agenda, calling for democratic change, social justice, and more freedom in education. The student movement, which Nepal's political leaders have often seen as a part of the broader socio-political movement (Snellinger 2005), has often maintained strong ideological connections with parent political parties and their struggle for political change.

During the Panchayat era (1961-1990), educational institutions, especially university campuses, were prime locations for debating political issues and organizing pro-democracy rallies. In this period, the communist movement also spread clandestinely while the regime faced a more popular threat from the Nepali Congress Party, whose majority government then became the victim of the 1960 royal coup. As one of the first communist rebellions in Nepal, a radical communist group, inspired by the Naxalite movement in West Bengal in India, launched a violent movement by killing several "class enemies" in eastern Nepal (Lawoti 2010, p. 5). Even though the struggle was brutally crushed by the regime, it infused radical views among young communist groups, particularly the All Nepal National Free Student Union (ANNFSU), a student union established on 14 May 1965 that was ideologically intimate with, and loyal to, the Communist Party of Nepal. In 1978, this extreme communist group was transformed into a moderate communist faction known as the Communist Party of 
Nepal (Marxist-Leninist); in 1994 it formed the world's first democratically elected communist government.

However, the radical communist ideology continued to prevail among several communist factions, which believed that armed rebellion was the only way to "smash" the long-established socio-political and cultural structures that served a small group of social elites (Maoist Statements and Documents 2003). A large number of school teachers, who were politically active during their student lives and conscious of the socio-cultural inequalities prevailing in Nepali society, were not enthusiastic about the state agenda of forging national identity and integration, an educational vision of the NESP. In some cases, they became involved in clandestine anti-regime political activities. As a head teacher from a private school in Udaypur explained during an interview,

The students from the universities, as they went to work in schools in the rural areas, would not only teach in the school but also outside their teaching hours, and communicate critical awareness about social and political issues along with the significance of education to the common people.

This phenomenon of socio-political campaigning by teachers continued, and even escalated, after the multiparty polity was restored and the moderate communist group CPN-UML participated in the post-1990 democratic process. When the armed conflict began, the state arrested, and falsely charged, many teachers, along with other supporters of the United People's Front, a communist faction that supported the CPN-M and the People's War; this helped to further intensify the conflict (Maoist Statements and Documents 2003). The 1990 restoration of party politics caused social fragmentation, not only among those involved in active politics but also within rural households, as people became divided along the lines of their ideological connections. The political divide transcended all sectors, including education, where students and teachers organized as the political wings of their respective parties (Vaux, Smith, and Subba 2006, p. 25). The use of young children in campaigns and mass demonstrations became a common practice. The CPN-M capitalized on the culture of widespread politicization in the education sector to promote its radical political views and rationalize the People's War as the only way to bring about socio-political change (Pherali 2011). For example, the ANNFSU-Revolutionary, the student wing of the CPN-M, along with the Nepal Republican Educational Front, the Maoist-affiliated teachers' union, actively participated in the People's War by engaging in violent assaults on security forces, leading revolutionary political campaigns in the education sector, and, more importantly, 
systematically attacking private schools, accusing them of being merely commercial ventures and spreading "Western influence" (Caddell 2006).

Hence, education is more than a means of cultural reproduction (Bourdieu 1984); it can also become a dynamic forum for developing and rehearsing active political roles which challenge social injustice. Fernandes (1988, p. 169) notes that the theory of social and cultural reproduction "ignores the individuals' actions and intentions and reduces the logic of domination to a structural determinism that escapes any challenges and transformation". $\mathrm{He}$ describes as "pessimistic and fatalistic" the idea that pupils and educators are passive recipients of hegemonic curricula imposed by the state and can therefore do nothing about the role of education in reproducing social inequalities (p. 169). Resistance to the structural determinants of the education system can also emerge within the autonomy of a school, where the space of the classroom and of its surrounding communities can be exploited and expanded by educators in order to exercise counter-hegemonic pedagogies.

Hence, the involvement of teachers and students in the Maoist uprising in Nepal cannot be explained entirely by the idea of violent intrusion into or victimization of schools; it must also be viewed as resistance to the schools' role in cultural and social reproduction, which Fernandes (1988, p. 171) depicts as the theory of resistance. Even though "reproduction" is dominant because of the power relations in the education system, the actions of teachers and students "can oppose the reproductive structural determinants". Hence, the same educational contexts provide empirical and analytical backgrounds for the theory of resistance (Fernandes 1988). Unlike the situation in other civil wars, the resisting role of education is key to the success of politically-driven armed conflicts that utilize revolutionary ideologies to gain support from youth to mobilize them against the regime.

\section{The contentious role of education in Nepal's People's War}

Bush and Saltarelli (2000) and others discuss the two faces that education can have during ethnic conflicts. It can play a positive role in reducing the potential for violent conflict by addressing root causes of political and socio-cultural tensions among different social and ethnic groups. It can also play a negative role, by reproducing and perpetuating favourable conditions for the social and political tensions that often develop into armed conflicts (see also Davies 2004; Pherali 2011; Shields and Rappleye 2008a; Smith and Vaux 2003). The notion of two faces of education is also relevant when analyzing Nepal's educational processes in the emergence and growth of the Maoist movement. 
Education and social disparities

The rapid expansion of school education in the 1960s and later decades did increase access to education but the government paid very little attention to the need to improve living conditions for the vast majority who have been historically marginalized in Nepali society. The educational benefits were largely limited to those who came from upper-caste groups and privileged backgrounds, and school dropout rates were high among girls, ethnic minorities, indigenous groups, and Dalits (Stash and Hannum 2001). Even at present, primary school net enrolment has reached $93.7 \%$ overall, but $34 \%$ of students drop out before completing basic education and only 55\% graduate from secondary schools on their first attempt (DoE 2010, 2011). Yadava (2007) shows that the majority of children who drop out of school come from ethnic/indigenous minority backgrounds and do not speak Nepali as their mother tongue.

This implicitly forced "rejection" of education by non-Nepali-speaking children limits their access to wider societal opportunities and contributes to reproducing social and economic disparities (Shields and Rappleye 2008b). Fernandes (1988, p. 171) notes that the oppositional attitudes, behaviors, and actions of the working class, and of racial and ethnic minority students towards schools and teachers often "lead them to their own school exclusion", which then reduces their chance of social mobility and reinforces social divisions. Therefore, the "rejection of school culture" by marginalized groups is not an element of "resistance" but rather the manifestation of social reproduction (Fernandes 1988, p. 172).

From a conflict perspective, when such socioeconomic disparities are present, all that is required to sustainably mobilize the marginalized populations against the state is a "political entrepreneur" who can utilize these factors to ignite conflict, and to continuously provide a sense of discrimination (Zartman 2005). Hence, poverty, discrimination, and social divisions are not necessarily sufficient conditions for the advent of an armed conflict (Collier and Hoeffler 2004); what may play the key role is charismatic leadership within these circumstances.

The educational development of the past four decades has only benefited the uppercaste social elites who monopolized social and political power. Bourdieu (1973, p. 71) explains that the education system contributes to reproducing "the structures of power relationships and symbolic relationships between classes, by contributing to the reproduction of the structure of the distribution of cultural capital among these classes". In other words, children inherit cultural capital from their parents, and the education system then legitimizes 
that capital, enabling them to control economic resources and maintain political hegemony. Thus the modern educational system legitimized the cultural, ethnic, and caste-based hierarchies of Nepali society, in which high-caste hill-based males were able to dominate the vital realms of public life.

Neupane (2000) found that two population groups, the high-caste hill-based groups and the Newars, represented $36.7 \%$ of the population in the 2001 census, but occupied $80 \%$ of the state's leadership positions in 12 different sectors, including the executive branch, parliament, the judiciary, public administration, the security forces, academia, industry and commerce, civil society, and cultural associations. Even in 2001, a full decade after multiparty democracy was restored, with equal rights spelled out in the new Constitution, and educational "development" efforts intensified, the literacy rate among Brahmins, the upper caste, was $70 \%$, compared with a dismal $10 \%$ among several low-status caste groups (CBS 2003). These statistics had significant effects on their capacity (or lack of it) to improve their living standards after the country started practicing democracy and adopted a liberal economy. During the period from 1995-1996 to 2003-2004, the poverty level among the Brahmins and Chhetris dropped by $46 \%$; however, for the Muslims, the hill indigenous nationalities, and the Dalits, those percentages were far smaller: 6\%, 10\%, and 21\% respectively (Tiwari 2010a, p. 74). In educational terms, these social conditions, which Bush and Saltarelli (2000) regard as "uneven distribution" and "denial of education", reinforced the society's "horizontal inequalities" (Stewart 2000); one result was "a high participation" of indigenous nationalities, Dalits, and women in the People's War (Lawoti 2005, p. 113).

The NESP, implemented in 1971, aimed at eliminating the traditions, languages, and cultures of indigenous nationalities and ethnic groups in order to create a homogenous national identity which mainly focused on three key aspects: loyalty to the monarchy as a symbol of national unity, Nepali as a national language, and Hinduism as a national religion (Burghart 1994; Onta 1996). In this process, education became one of the major tools of national intervention, particularly through the imposition of a national curriculum. The MoE (1971) spelled out the goals of the education system under the NESP:

[...] to strengthen devotion to crown, country, national unity and the Panchayat system, to develop uniform traditions in education by bringing together various patterns under a single national policy, to limit the tradition of regional languages, to encourage financial and social mobility, and to fulfil manpower requirements essential for national development. (p. 1) 
The government pursued the goal of developing "uniform traditions" through education by nationalizing the country's community schools and distributing textbooks that ignored the reality of cultural and linguistic diversity in Nepali society. This was a further escalation of the linguistic repression through the education system that had started as early as 1956 when the first official educational report in the country's history explicitly described the expected role of Nepali: "If the younger generation is taught to use Nepali as the basic language then other languages will gradually disappear, and greater national strength and unity will result" (Pandey, K.C., and Wood 1956, p. 97).

Graham-Brown (1994) notes that the control of a government by a particular social or ethnic group can lead to the construction of a particular version of national identity which reflects the group's cultural values by maintaining their dominance and neglecting the traditions and cultural values of those who are marginalized. The state apparatus, overwhelmingly dominated by the high-caste hill-based groups, who represented approximately one-third of the population in the 2001 census (Neupane 2000), promoted their own language (Nepali), culture (national uniforms, festivals, and life styles) and religion (Hinduism) as the emblem of Nepali national identity. It became necessary for other groups in the country to adopt these elements if they were to participate fully in the social, political, and economic spheres of the country. They also prevented ethnic and indigenous groups who were not Nepali-speaking from succeeding in education (Ragsdale 1989) and entering into a range of civil services including the educational sector. As Ragsdale (1989) noted, "Nepal's small, elitist system of education had been expanded without regard for its suitability to the country's needs"; it mainly served the purposes of the regime and promoted its character rather than creating a system that contributed effectively to the entire country's economic development (p. 15). Hence, the regime systematically (mis)used education "as a weapon in cultural repression" (Bush and Saltarelli 2000, p. 10) against different ethnic groups and indigenous nationalities. Gurung $(1998,2003)$ provides a detailed analysis of the ethnic demography of Nepal.

\section{Education for social awareness}

As discussed earlier, education contributed in several ways to reproducing the social order by mainly benefiting the historically privileged castes and social groups. However, schools also served as a forum for critical discourses. Interviews with teachers indicate that they played crucial roles in laying the foundations for the socio-political movement. This shows that, at 
one level, teachers and learners can implicitly resist the political purpose of education envisaged by the regime, which is to gain social control by reinforcing the "cultural legitimacy of the knowledge of specific groups" (Apple 2004, p. 61). One teacher from a government school in the eastern mountains explained the political role of schools:

Teachers and students are the people who best understand the political situation, the country's situation, and therefore, every political group would try to gain teachers' and students' support so their movement would succeed. Since the time when teachers fought against the Panchayat regime, they have been perceived as anti-government elements, as they often advocated for progressive changes in society and encouraged such values in students to get them to protest against the country's autocratic rules.

This teacher depicts the relationship between teachers and the state as sensitive and cautious, but also shows that the regime's goal of maintaining control over society is potentially at risk because teachers hold progressive views on society and can transfer those views to the younger generation and to people in their local communities. Fernandes (1988, p. 170) describes how, within the political hegemony of schooling, teachers can exploit the school's autonomy by organizing alternative curricula and introducing young people to critical debates with a view to challenging the schools' role in the "reproduction of social inequality". Political uprisings against the cultural hegemony of a state often capitalize on the potential for educational resistance; hence, teachers and educational institutions are often drawn into struggles that involve explicit ideological underpinnings and mass mobilization for political change.

The Maoists used this fact to mobilize youth groups in favour of their movement. Schools provided easy access to masses of young educated people who could be recruited for the militia and trained politically to carry out violent acts. Schools also became the target of security forces, who frequently abused teachers and school children (Watchlist 2005). Consequently, schools were caught in the crossfire: a situation that is still far from being resolved, even after the CPA was signed and the peace process began.

\section{Schools in the crossfire: Experiences of teachers and students during the conflict}

Educational institutions, particularly schools in rural areas, came under attack by both warring parties during Nepal's decade-long civil war (Sharma and Khadka 2006; Watchlist 2005). INSEC (2007) reported that the Maoists destroyed more than 79 schools, one university, and 13 district education offices between January 2002 and December 2006; of these, 32 suffered 
bomb explosions and at least three schools were caught in the crossfire between the rebels and security forces. Most of the schools the Maoists targeted were privately managed institutional schools, as the CPN-M declared an ideological war on private education. District education offices became obvious targets as they represented the Maoists' major enemy: the government or "old state". In contrast, their "new state" consisted of people's councils, parallel government structures across the country, and military (People's Liberation Army), judiciary (people's courts) and executive (the CPN-M party politburo) functions.

Private schools came under attack as they provided English-medium education to children representing socially privileged groups and were operated as business enterprises. The Maoists demanded several changes: "reduction of school fees; the removal of reference to the monarchy in school activities, including the singing of the national anthem; the prevention of 'Western influence' in teaching; and, ultimately, the nationalization of schooling" in order to end the two-tiered education system (Caddell 2006, p. 471). Schools that did not comply with their demands often experienced violent attacks on school buildings and infrastructure and school principals were physically punished.

\section{Attacks on teachers}

Schools were also targets for security personnel who arrested, tortured, and even killed teachers and school children they suspected of being Maoist activists or sympathisers (Amnesty International 2005; CWIN 2004; Dhital 2006). The state committed far more atrocities and violations of human rights than did the Maoists (INSEC 2007), who engaged in "demonstration killing" of teachers and school principals to terrorize their opponents (Lawoti and Pahari 2010, p. 309). For example, Muktinath Adhikari, a head teacher in Lamjung, was teaching a lesson when Maoists abducted him, killed him within an hour, and left his body tied to a tree. This is documented in Schools in the Crossfire (Basnet 2004), a film that also captures the traumatic experiences of Adhikari's colleagues at the school, of the students who resisted his abduction, and of his orphaned children. A Maoist leader defended this behavior in the documentary, maintaining that 'those who stand against the 'great' 'People's War' are class enemies and therefore not spared. We [Maoists] turn cruel to them". However, in the absence of any truth and reconciliation efforts after the conflict, few people have any idea what Adhikari did wrong, or the hundreds of other teachers, parents, and children accused of "stand[ing] against" the Maoist movement. 
Teachers interviewed in the documentary described how they were trapped in the middle of the conflict which resulted in loss of professional motivation, as their prime concern during the conflict was how to survive. Similarly, they said the Maoists suspected them of spying on rebel activities, and the security forces frequently harassed them, accusing them of colluding with the Maoists against the state or of harboring Maoists. In total, the warring parties killed 145 teachers during the conflict (INSEC 2007). Furthermore, teachers in the Maoist stronghold faced a dilemma: Should they implement the new "Maoist curriculum", or continue with the government-prescribed "national curriculum"? In some rural areas, the Maoists enforced their own academic calendar and replaced the national anthem with a revolutionary song (Basnet 2004).

In rural areas, schools provided young recruits for the insurgency, and school premises were often captured as shelters by both warring parties (Watchlist 2005). In some places, school buildings were turned into military barracks, preventing any teaching and learning there. By 2004, an estimated 3,000 teachers had been displaced from schools in the rural areas, directly impacting the education of an estimated 100,000 students (Thapa and Sijapati 2004). A significant number of the displaced teachers whom I interviewed in Rolpa and Sankhuwasabha in 2008 were still based in district headquarters and some cited security as the main reason why they could not return to their designated schools.

During the conflict, teachers were forced to make donations to the Maoists as a “contribution" to the People's War. According to teachers I interviewed, and as reported in the documentary, this requirement caused them deep psychological distress. They were trapped: forced to decide whether to comply with the Maoist demand for money. If they did not comply, they risked their own safety; if they did comply, they risked being identified as a Maoist supporter by the security forces. The head teacher of a government school in Sankhuwasabha reported these tensions and violent experiences:

The Maoists had been demanding money from us [teachers in the school] for a long time. I [the head] had been getting letters. Once they took a friend and me some five to seven hours away from [the school] and we negotiated with one of their commanders that we could offer them a one-month equivalent salary instead of their original demand of one month each for the last three years. After we returned from that meeting, we collected 28,000 rupees, but had no idea how to get the money to them. Then one day a man came and asked me to come out of the house. I went out carrying the money and when we had gone a little distance he asked me about the money. I gave him what I had and asked him to give me a receipt. When I said that, he took out a gun and took me to a school near the jungle, beating me all the way. Luckily, one of the cadres was a former student who had graduated from my school and who 
eventually negotiated my release. But that incident traumatized me and ruined my Dashain celebration [the greatest Hindu festival observed for two weeks] that year.

As these narratives show, teachers lived in extremely uncertain and risky situations, facing both financial demands from the rebels and the danger of being caught by the security forces if they did make contributions. Teachers and children were also caught in actual crossfire between Maoist rebels and security forces. In one incident in October 2003, 11 young people, including four students, were killed in the Sharada Secondary School in Mudbhara in Doti, when security forces opened fire indiscriminately at members of the Maoist cultural group who had gathered in the school to perform a cultural show as part of their political campaign. The school soon turned into a battlefield and graveyard, leaving local people and children devastated. Even five years after this traumatic incident, teachers and children in Mudhbhara said the violence had done irreparable damage, as can be seen from interviews with a male and a female teacher in a community school in Doti:

Interviewer: Where were you, Sir, when the incident took place?

Male teacher: I was in the school, hiding behind a cabinet when the army and the Maoists were firing the bullets. Later a teacher came and asked me to come out, and while we were walking out of the room we heard the army shout at us. They were saying: "We will kill you, we will shoot you".

Interviewer: And where were you, Miss?

Female teacher: We were also here [in the school]. We came out when we heard them yell, "Shoot! Shoot!" They said, "Shoot from the roof". We were so scared when they asked us to put our hands up that we could not even lift our hands. They fired despite seeing the students in their school uniforms. [...] they came and instantly opened fire.

Teachers reported that their professional "morale and motivation" almost collapsed because they had such stressful experiences during the conflict; Ezati, Ssempala and Ssenkusu (2011) describe similar events in Northern Uganda. In a group interview, one of the teachers in a community school in Doti reported:

Our enthusiasm and energy have run out of steam. During the conflict, we had virtually none. You never knew what would happen when, and the mental pressure reduced our interest in teaching students. 
The state's failure to protect schools during the conflict caused the public to lose most of its trust in government institutions. Now, members of professional groups, including teachers who suffered violent attacks, have aligned themselves with their unions, which are affiliated with political parties. Consequently, the combination of declining professional morale and their emphasis on personal security has led them to place far more confidence in political patronage than in formal governance.

Attacks on children

The conflict had an immense impact on children's education because of the massive scale of internal displacement (Lawoti and Pahari 2010; Raj 2004) and the frequent lockouts (strikes) that the Maoists called as a tactic to demonstrate their strength and incapacitate government functioning (Thapa and Sijapati 2004). In most parts of the country, school children and teachers were forcibly taken away from their schools to attend Maoist political training or mass meetings of the CPN-M. These experiences were traumatic and enduring, as described by a government school teacher in Sankhuwasabha:

I was working in Jana Jyoti Secondary School. And after the People's War started, all the teachers and students in the schools were forcefully taken by the Maoists to a distant place called Devitar where their political training session was underway. Those students who had heard about past abductions of school children were generally able to cope with the fear but most others got very scared and cried constantly. They had taken us to be trained about the achievements of the People's War up to that date.

The risk of abduction from school put enormous pressure on teachers, who were unable to resist Maoist intrusions into their schools. Teachers in Udaypur indicated that the relationship between the school and the parents deteriorated as parents held teachers accountable for the security of their children during school hours. They claimed that schools, and those in them, were frequently attacked, intimidated, and victimized during the conflict and that they could not imagine any way to prevent external interference in the school while the entire nation was engulfed in a bloody civil war. Elsewhere, parents of children in a private school in Kathmandu held opposing views about how their school dealt with the Maoist pressure for mandatory donations. The principal of this school described how some parents objected to providing financial support to the Maoists, while others blamed the school management for not complying with Maoist demands, thereby inviting attacks on the school and endangering the lives of their children. 
The security forces also arrested students, suspecting them of maintaining secretive connections with the Maoist student wing ANNFSU-R which the government also labelled a “terrorist group". Students in a private school in Liwang, in Rolpa, told us that their schooling experience during the conflict involved great anxiety and uncertainty about their educational future. Children in all the selected schools said they were often harassed and intimidated by security forces on patrols or at security checkpoints. Some parents in Kapilvastu district reported that they were compelled to withdraw their boys from school and send them away to work, hoping they would at least escape being forcibly recruited into the Maoist army. Osofsky (1995, pp. 785-786) notes that the loss of trust in "traditional societal protectors" of children, such as schools, would lead parents to assume additional burdens; ultimately, the community's sense of fear would "interfere with normal developmental transitions for both parents and children". When parents are also traumatized in violent situations, they lose their ability to "play a stable, consistent role in the child's life" and "are more likely to have difficulty being emotionally available, sensitive, and responsive to their children" (Osofsky 1999, pp. 40-41).

INSEC (2007) reported that 33,160 children in Nepal were abducted from schools to join political campaigns. Many were later released, but some were killed in the crossfire or the aerial attack by the state army while "others joined the movement voluntarily or under pressure" (Lawoti and Pahari 2010, p. 310). An estimated 475 children died during the conflict and 562 sustained injuries either in the crossfire or in explosions (CWIN 2004). Hence, children were victimized by both the state and the Maoists. Only in February 2010, four years after the CPA, were nearly 3,000 minors released by the People's Liberation Army (United Nations 2010).

In the post-war period, teachers reported a noticeable change in students' attitudes towards learning and future aspirations and in their general behaviour, which they described as aggressive and lacking discipline (Ezati, Ssempala and Ssenkusu 2011). The power relations between teachers and students also shifted, allowing students more freedom and rights in their educational experiences. This has affected students' ability to engage fully in learning, as a teacher from a private school in Kathmandu described:

[...] in the aftermath of the conflict, students seem to have lost creativity; they are more aggressive and often display irritation. Most students at the secondary level show a high degree of schizophrenic symptoms.

Post-war educational reforms 
The post-accord political processes have largely ignored the impact that the decade-long conflict has had on education. The post-war strategic interventions that the Ministry of Education (MoE 2009) proposed in its School Sector Reform Plan 2009-2015 (SSRP) are oblivious to the need for a "conflict-sensitive" approach to educational reforms (Smith 2005, p. 377). Apart from providing slim scholarships for girls, Dalits, and children whose parents died in the conflict, the plan largely disregards the impact that the decade of violence had on education and ignores the structural problems and educational inequalities that contributed to the Maoist insurgency. The culture of the privileged social groups is still dominant in the curriculum, the medium of instruction, and various forms of assessment that largely favour those who hold the power in the society, the economy, and the political domain. The massive investment in education proposed in the SSRP is unlikely to affect the legacy of politicallydriven violent insurgency or the system's longstanding deficiencies and the structural inequalities it perpetuates. This is reflected in the continued violence in the education system. Violence is now expressed in different ways but it has more damaging long-term effects, including institutional corruption, political interference, and the prominence of the patronage system.

In this context, the development partners we interviewed in February 2011 were increasingly questioning the effectiveness of educational aid, and of Nepal's commitments to global educational targets that have now become the "de facto" national policies (Bhatta 2011). As Bhatta (2011, p. 22) argues, after the Jomtien and Dakar world meetings on Education for All, "there has been an increasing use of coercive pressures (or conditions)" on the MoE "to ensure the conformity" to the global framework of action. Consequently, there is a false perception of country "ownership over the educational agenda"; in reality, the MoE's role is largely "limited to the management of aid processes" rather than determining the development of a national policy framework (Bhatta 2011, p. 22). Hence, the notion of mutual cooperation and learning from all actors, including donors and national governments (Buchert 2002) has in reality become only a formality in a situation where development partners play the more powerful and dominant roles (Klees 2001; Samoff 2004). This has led to the neglect of local needs and to compliance with policy reforms that address technical issues raised in the global policy discourse (e.g. access, quality, infrastructural development, teacher training, etc.) rather than engaging with more deeply-rooted problems in education: social and political exclusion, linguistic repression, discrimination based on caste, ethnicity, and gender, etc. This situation undermines the increased efforts of development partners to provide technical 
solutions that can improve the education system, because no one is addressing the issue of unjust social and political structures.

\section{The continued political impact on education in post-conflict Nepal}

A political economy analysis (PEA) of the education sector highlights the extent to which political affiliation and economic motivation continue to have an impact on educational provision. The PEA is concerned with "the distribution of power and wealth between different groups and individuals, and the processes that create, sustain and transform these relationships over time" (Collinson 2003, p. 3). In a post-war situation, the PEA of education examines both "the political and the economic aspects" of education and conflict and "how these combine to affect patterns of power and vulnerability" in the education sector (Collinson 2003, p. 3).

One of the major impacts that the decade-long civil war has had on education since the 2006 signing of the CPA is the increased politicization of the education system that has become an important arena for political struggles. In particular, education policy is determined by the declared ideological commitments of various political parties without any consideration for the practical implications: How will they be implemented? The regime's ideological interventions in education are perhaps not unusual. As Apple (2004, p. 61) noted, education is a "political act" and schools are "caught up in a nexus of other institutionspolitical, economic, and cultural — that are basically unequal". However, in the context of Nepal, politicization is predominantly a form of corruption by influential people or political groups within or outside the education system. Interviews with educational stakeholders in rural areas, including teachers, local politicians, and students, revealed that school management committees (SMCs) have become more politicized, and political parties have mobilized support for elections to these bodies based on ideological commitment rather than on educational policies that serve the best interests of children.

In the last decade of armed conflict, Nepal has suffered a significant loss in social and political stability, resulting in a breakdown of state institutions and a spread of party-based politics into all public sectors, including education. All educational stakeholders-including teachers, head teachers, SMCs, and district education officers (DEOs) — are affiliated with political parties and have their own political and economic interests in education. Our interviews with educational stakeholders in ten districts across Nepal indicated that many ordinary functions - including educational management and bureaucracy, teacher recruitment 
and redeployment, DEO transfers, school upgrades, and elections of SMCs - all involved political interference and corruption.

The corruption and politicization at the local level can be seen as a by-product of the unsuccessful decentralization of education (Edwards 2011), and the weak governance and absence of local government during the last decade. Ironically, however, this marked political upheaval has also led to improved public participation, with historically suppressed castes and indigenous nationalities challenging the assumed dominance of the state. This has put pressure on the state restructuring process, which should guarantee a more inclusive democracy in all sectors. In this transformation, primary education in the mother tongue has become a popular slogan for Terai-based ethno-regional political parties and the SSRP includes an effort to provide primary education in the child's mother tongue in 7,500 schools by 2015 (MoE 2009, p. 14). While substantial empirical evidence supports the argument that education in the child's first language brings "the most positive educational outcomes" (Taylor 2010, p. 140), this policy initiative, which partly aims at addressing political concerns, may not achieve much success. Many parents prefer not to educate their children in the local language. Parents in Dhanusha, Kapilvastu, and Kathmandu argued in interviews that imposing the local language on children of ethnic and indigenous minority groups is a political ploy that would further exclude them by restricting their full participation in wider economic opportunities.

\section{Schools as power centres: School management committees as political entities}

Decentralization of public school management is often considered to be an effective approach that results in "increased efficiency, greater accountability and equity, and more democratic decision making processes" through the involvement of local communities (Edwards 2011, p. 67; Carney and Bista 2009; Carney, Bista and Agergaard 2007). But this process has also been criticized as a "policy disconnect" in which globalized policy agendas fail to engage with community-level educational stakeholders (Edwards 2011), resulting in "unsatisfactory" project outcomes (World Bank 2010). In interviews, head teachers and SMC chairs indicated that one of the main reasons for community involvement was the financial support provided by the Community School Support Programme. This policy initiative, which facilitated the process of educational decentralization, provided funding to schools as a perk in return for transferring to the new system of local management. The respondents said these funds were crucial to build an extra classroom or employ a new teacher. But both teachers and the 
Maoists were opposed to the concept of management transfer, and the local communities failed to engage effectively in school management; together these situations largely defeated the purpose of educational decentralization (World Bank 2010). Furthermore, the role of SMCs is unclear and they often do not have the capacity to monitor and supervise teaching and learning.

The SMCs are politicized for a number of reasons rooted in the conflict period. The lack of local government since the local councils were dissolved in July 2002 has turned schools into a platform for exercising political power at the local level. Because political parties try to maintain power through representatives on the SMCs, schools have become political entities that reflect contesting political ideologies. Furthermore, holding an SMC position, particularly the chair, provides a respectable social status that can further one's political career in a party. The SMCs influence the spending of government funds that are provided directly to the schools, including per capita funding, school development plan funds, and scholarship money; this creates opportunities for members of SMCs to benefit economically, and helps political representatives gain social credibility. Therefore, securing the position of SMC chair has become the subject of intense political competition, especially in the Terai district and in places where schools own land and other properties that generate income. This situation shows that the educational sector is overly politicized, not in the sense of pursuing an ideologically-driven educational vision but in its maintenance of a pervasive rent-seeking culture.

\section{Conclusions: Post-conflict challenges for education}

Even though the violent conflict in Nepal has formally ended, schools continue to be affected by tensions that are likely by-products of the decade-long political violence and the government's decentralization policy. In the absence of effective local governments, public services, including schools, have become de facto political centres where party cadres exercise their political interests. In addition, the transitional politics and the on-going peace process raise the fear of uncertainty among political parties that struggle constantly to maintain and renew their support among members of local communities. Thus, the decadelong armed conflict has intensely politicized educational processes, leading to increased corruption and political patronage in the education system.

Attacks on teachers during the conflict and the impact of direct or symbolic violence on school education have broader implications for the post-accord policy framework. In the 
prolonged transitional period, the voices of victims of conflict in the education sector have been neglected; more importantly, the debate on educational reconstruction in the "new Nepal" deserves more attention. This is especially so because the nation is in the process of promulgating a new constitution and restructuring the state with implications for the future education system.

At this political juncture, Nepal has tremendous opportunities to radically reform education in a bid to address deep structural inequalities. However, the excessive politicization of both the education system and other state institutions poses serious threats to such reforms. This means that technical solutions for school effectiveness that disregard the need for "conflict-sensitive" educational reforms (Smith 2005) are likely to be undermined by the contesting political and economic interests within the education system; thus development partners are likely to play a complicit role in continuing to politicize education.

The post-war PEA of education indicates that the increased aid and continuous thrust toward decentralizing education are more likely to perpetuate existing power relations within the education system than to transform them in the post-conflict political environment. This situation damages the education system, covertly and more aggressively than during the violent conflict. Meanwhile, opportunities for post-conflict peace-building through education are being lost. Therefore, development partners need to be more critical, about both their own development strategy and the state leadership's capacity to negotiate transformation among the diverse political forces in the country.

\section{References}

Alvesson, M., \& Sköldberg, K. (2009). Reflexive methodology: New vistas for qualitative research. London: Sage.

Amnesty International (2005). Nepal: Children caught in the middle. Kathmandu: Amnesty International.

Apple, M. (2004). Ideology and curriculum (3rd ed.). London: Routledge Falmer.

Basnet, D. (2004). Schools in the crossfire (film). Kathmandu: Himal Books Clearinghouse for South Asian Non-fiction Film.

Bhatta, P. (2011). Aid agency influence in national education policy-making: A case from Nepal's "Education for All movement". Globalisation, Societies and Education, 9, $11-26$.

Bhattarai, B. R. (2003). The political economy of the "People's War". In A. Karki \& D. 
Seddon (Eds.), The people's war in Nepal: Left perspectives (pp. 117-164). New Delhi: Adroit Publishers.

Bohara, A. K., Mitchell, N.J., \& Nepal, M. (2006). Opportunity, democracy, and the exchange of political violence: A subnational analysis of conflict in Nepal. Journal of Conflict Resolution, 50, 108-128.

Bourdieu, P. (1973). Cultural reproduction and social reproduction. Knowledge, Education and Cultural Change, 10(2), 71-112.

Bourdieu, P. (1984). Distinction: A social critique of the judgment of taste. London: Routledge and Kegan Paul.

Buchert, L. (2002). Towards new partnerships in sector-wide approaches: Comparative experiences from Burkina Faso, Ghana and Mozambique. International Journal of Educational Development, 22, 69-84.

Burghart, R. (1994). The political culture of Panchayat democracy. In M. Hutt (Ed.), Nepal in the nineties: Versions of the past, visions of the future (pp. 1-13). Delhi: Oxford University Press.

Bush, K., \& Saltarelli, D. (2000). The two faces of education in ethnic conflict: Towards a peacebuilding education for children. Florence: UNICEF Innocenti Research Centre.

Caddell, M. (2006). Private schools as battlefields: Contested visions of learning and livelihood in Nepal. Compare: A Journal of Comparative Education, 36, 463-479.

Carney, S., Bista, M., \& Agergaard, J. (2007). Empowering the "local” through education? Exploring community-managed schooling in Nepal. Oxford Review of Education, 33, 611-628.

Carney, S., \& Bista, M. B. (2009). Community schooling in Nepal: A genealogy of education reform since 1990. Comparative Education Review, 53, 189-211.

CBS [Central Bureau of Statistics] (2003). Population monograph of Nepal, vol. 1. Kathmandu: National Planning Commission Secretariat.

Collier, P., \& Hoeffler, A. (2004). Greed and grievance in civil war. Oxford Economic Papers, 56(4), 563-595.

Collinson, S. (Ed.) (2003). Power, livelihoods and conflict: Case studies in political economy analysis for humanitarian action. HPC Report 13. London: Overseas Development Institute. http://www.odi.org.uk/hpg/papers/hpgreport13.pdf.

CWIN [Child Workers in Nepal Concerned Centre] (2004). The state of the rights of the child in Nepal 2004. Kathmandu: CWIN. 
http://www.crin.org/docs/resources/treaties/crc.39/Nepal_CWIN_nationalstatusreport1 .pdf.

Davies, L. (2004). Education and conflict: Complexity and chaos. London: Routledge Falmer. Deraniyagala, S. (2005). The political economy of civil conflict in Nepal. Oxford Development Economics, 33, 47-62.

DfID [Department for International Development] (2009). Political economy analysis: How to note. London: DfID.

Dhital, T. (2006). Sashastra dwandako chapetama balbalika: Sashastra dwandaka kramma mritu, ghaite, pakrau tatha apaharanma pareka balbalikako biwaran 1996-2006 [Children caught in the armed conflict: Details of the children dead, wounded, arrested and abducted during the armed conflict 1996-2006]. Kathmandu: CWIN Nepal.

Do, Q. T., \& Iyer, L. (2007, May). Poverty, social divisions and conflict in Nepal. World Bank Policy Research Working Paper 4228. Washington, DC: World Bank. http://documents.worldbank.org/curated/en/2007/05/7581269/poverty-socialdivisions-conflict-nepal

DoE [Department of Education, Government of Nepal] (2010). Flash I report 2067 (20102011). Sanothimi, Bhaktapur: DoE.

DoE [Department of Education, Government of Nepal] (2011). The SLC results. Sanothimi, Bhaktapur: DoE.

Edwards, R. M. (2011). Disconnect and capture of education decentralisation reforms in Nepal: Implications for community involvement in schooling. Globalisation, Societies and Education, 9, 67-84. DOI: 10.1080/14767724.2010.513532.

Ezati, B. A., Ssempala, C., \& Ssenkusu, P. (2011). Teachers' perceptions and the effects of young people's war experiences on teaching and learning in Northern Uganda. In J. Paulson (Ed.), Education, conflict and development (pp. 185-207). Oxford: Symposium.

Fernandes, J. V. (1988). From the theories of social and cultural reproduction to the theory of resistance. British Journal of Sociology of Education, 9(2), 169-180.

Graham-Brown, S. (1994). The role of the curriculum: Education rights and minorities. London: Minority Rights Group.

Gramsci, A. (1971). Selections from the prison notebooks. London: Lawrence and Wishart.

Grbich, C. (2007). Qualitative data analysis: An introduction. London: Sage.

Griffith, A. I. (1998). Insider/outsider: Epistemological privilege and mothering work. Human Studies, 21(4), 361-376. 
Gurung, H. (1998). Nepal: Social demography and expressions. Kathmandu: New Era.

Gurung, H. (2003). Social demography of Nepal: Census 2001. Lalitpur, Nepal: Himal Books.

INSEC [Informal Sector Service Centre] (2007). Human rights yearbook. Kathmandu: INSEC.

Klees, S. J. (2001). World Bank development policy: A SAP in SWAPs clothing. Current Issues in Comparative Education, 3, 110-121.

Kumar, D. (2003). Consequences of the militarized conflict and the cost of violence in Nepal. Contributions to Nepalese Studies, 30, 167-216.

Lai, B., \& Thyne, C. (2007). The effects of civil wars on education, 1980-97. Journal of Peace Research, 44, 277-292.

Lawoti, M. (2005). Towards a democratic Nepal: Inclusive political institutions for a multicultural society. London: Sage.

Lawoti, M. (2010). Evolution and growth of the Maoist insurgency in Nepal. In M. Lawoti \& A. Pahari (Eds.), The Maoist insurgency in Nepal: Revolution in the twenty-first century (pp. 3-30). Oxford: Routledge.

Lawoti, M., \& Pahari, A. (2010). Violent conflict and change: Costs and benefits of the Maoist rebellion in Nepal. In M. Lawoti \& A. Pahari (Eds.), The Maoist insurgency in Nepal: Revolution in the twenty-first century (pp. 304-327). London: Routledge.

Maoist Statements and Documents (2003). Maoist statements and documents. In A. Karki \& D. Seddon (Eds.), The people's war in Nepal: Left perspectives (pp. 183-287). New Delhi: Adroit.

Mercer, J. (2007). The challenges of insider research in educational institutions: Wielding a double-edged sword and resolving delicate dilemmas. Oxford Review of Education, $33(1), 1-17$.

Merton, R. (1972, July). Insiders and outsiders: A chapter in the sociology of knowledge. American Journal of Sociology, 78, 9-47.

MoE [Ministry of Education, Nepal] (1971). The National Education System Plan for 19711976. Kathmandu: MoE.

MoE [Ministry of Education, Nepal] (2009). School Sector Reform Plan (2009-2015). Kathmandu: MoE.

Murshed, S. M., \& Gates, S. (2005). Spatial-horizontal inequality and the Maoist insurgency in Nepal. Review of Development Economics, 9, 121-134. 
Neupane, G. (2000). Nepal ko jatiya prashna: Samajik banot ra rajhedari ko sambhawana [Nepal's caste and ethnicity question: Social composition and possibility of accommodation]. Kathmandu: Centre for Development Studies.

Novelli, M., \& Cardozo, M. (2008). Conflict, education and the global South: New critical directions. International Journal of Educational Development, 28, 473-488.

Onta, P. (1996). Ambivalence denied: The making of rastiya itihas in Panchayat era textbooks. Contributions to Nepalese Studies, 23, 213-254.

Osofsky, J. D. (1995). The effects of exposure to violence on young children. American Psychologist, 50(9), 782-788.

Osofsky, J. D. (1999). The impact of violence on children. The Future of Children, 9(3), 3349.

Østby, G., \& Urdal, H. (2011). Education and conflict: What the evidence says. CSCW Policy Brief 02/2011. Oslo: Center for the Study of Civil War. http://www.humansecuritygateway.com/documents/PRIO_EducationandConflict.pdf

Pandey, R. R., K. C., K. B., \& Wood, B. H. (Eds.) (1956). Education in Nepal: Report of the Nepal National Education Planning Commission. Kathmandu: College of Education.

Paulson, J., \& Rappleye, J. (2007). Education and conflict: Essay review. International Journal of Educational Development, 27, 340-347.

Pherali, T. J. (2011). Education and conflict in Nepal: Possibilities for reconstruction. Globalisation, Societies and Education, 9 (1), 135-154.

Ragsdale, T. A. (1989). Once a hermit kingdom: Ethnicity, education and national integration in Nepal. Delhi: Manohar Publications.

Raj, P. A. (2004). Maoist in the land of Buddha: An analytical study of the Maoist insurgency in Nepal. Delhi: Nirala Publications.

Rappleye, J. (2011). Different presumptions about progress, divergent prescriptions for peace: Connections between conflict, development and education in Nepal. In J. Paulson (Ed.), Education, conflict and development (pp. 59-98). Oxford: Symposium.

Riessman, C. K. (1993). Narrative analysis: Qualitative research methods. London: Sage Publications.

Samoff, J. (2004). From funding projects to supporting sectors? Observation on the aid relationship in Burkina Faso. International Journal of Educational Development, 24, $397-427$.

Sharma, R., \& Khadka, B. (2006). Impact of armed conflict in education. Kathmandu: Education Journalists Group, Nepal. 
Seitz, K. (2004). Education and conflict: The role of education in the creation, prevention and resolution of societal crises. Consequences for development cooperation. Eschborn: German Technical Organization. http://www2.gtz.de/dokumente/bib/05-0160.pdf.

Shields, R., \& Rappleye, J. (2008a). Differentiation, development, (dis)integration: Education in Nepal's “People's War”. Research in Comparative International Education, 3(1), 91-102. http://dx.doi.org/10.2304/rcie.2008.3.1.91.

Shields, R., \& Rappleye, J. (2008b). Uneven terrain: Educational policy and equity in Nepal. Asia Pacific Journal of Education, 28, 265-276.

Silverman, D. (2010). Doing qualitative research (3rd ed.). London: Sage.

Smith, A. (2005). Education in the twenty-first century: Conflict, reconstruction and reconciliation. Compare, 35, 373-391.

Smith, A., \& Vaux, T. (2003). Education, conflict and international development. Issues paper. London: Department for International Development.

Snellinger, A. (2005). A crisis in Nepali student politics? Analyzing the gap between politically active and non-active students. Peace and Democracy in South Asia, 1, 1844.

Stash, S., \& Hannum, E. (2001). Who goes to school? Educational stratification by gender, caste, and ethnicity in Nepal. Comparative Education Review, 45, 354-378.

Stewart, F. (2000). Horizontal inequalities: A neglected dimension of development. Working paper. Oxford: Centre for Research on Inequality, Human Security and Ethnicity, University of Oxford.

Taylor, S. (2010). Beyond bilingual education: Multilingual language education in Nepal. Gist Education and Learning Research Journal, 4, 138-154.

Thapa, D., \& Sijapati, B. (2004). A kingdom under siege: Nepal's Maoist insurgency, 1996 to 2004. London: Zed Books.

Tiwari, B. N. (2010a). Horizontal inequalities and violent conflict in Nepal. In M. Lawoti \& A. Guneratne (Eds.), Ethnicity, inequality and politics in Nepal (pp. 55-92). Kathmandu: Himal Books.

Tiwari, B. N. (2010b). An assessment of causes of conflict in Nepal. In M. Lawoti \& A. Pahari (Eds.), The Maoist insurgency in Nepal: Revolution in the twenty-first century (pp. 241-262). London: Routledge.

UNESCO (2010). Education under attack. Paris: UNESCO.

UNESCO (2011). The hidden crisis: Armed conflict and education. EFA Global Monitoring Report. Paris: UNESCO. 
United Nations (2010, 8 February). Nepal: UN hails release of all child soldiers by Maoists. http://www.un.org/apps/news/story.asp?NewsID=33696\&Cr=Nepal\&Cr1

Vaux, T., Smith, A., \& Subba, S. (2006). Education for All-Nepal: Review from a conflict perspective. Kathmandu: International Alert.

Watchlist (2005). Caught in the middle: Mounting violations against children in Nepal's armed conflict. New York: Watchlist on Children and Armed Conflict.

World Bank (2010). Project performance assessment report Nepal: Community School Support Project (CR. 3808). http://wwwwds.worldbank.org/external/default/WDSContentServer/WDSP/IB/2010/08/02/00033 3038_20100802012209/Rendered/PDF/554070PPAR0p111Official0Use0Only161.pdf

Yadava, Y. P. (2007, August). Linguistic diversity in Nepal: Perspectives on language policy. Paper presented at the Seminar on Constitutionalism and Diversity, Kathmandu. http://www.uni-bielefeld.de/midea/pdf/Yogendra.pdf

Zartman, W. I. (2005). Need, creed, and greed in intrastate conflict. In C. J. Arnson \& W. A. Zartman (Eds.), Rethinking the economics of war: The intersection of need, creed, and greed (pp. 256-284). Baltimore: Johns Hopkins University Press.

\section{Author Biography}

Tejendra Pherali (Nepal) is a senior lecturer in Education Studies and Sociology at Liverpool John Moores University in the UK. He is interested in the broad areas of globalization, international and comparative education, conflict analysis, and education for peace-building. 